\title{
Shared decision-making for the management of small renal masses - development and acceptability testing of a novel patient decision aid
}

Kristen McAlpine, MD ${ }^{1}$; Rodney H. Breau, MD, MSc, FRCSC ${ }^{1,2}$; Dawn Stacey, RN, PhD, FCAHS, $\mathrm{CON}(\mathrm{C})^{2,3}$; Christopher Knee, ND, MSc ${ }^{1,2}$; Michael A.S. Jewett, MD, FACS, FRCSC ${ }^{4}$;

Philippe D. Violette, MD, MSc, FRCSC ${ }^{5}$; Patrick O. Richard, MD, MSc, FRCSC ${ }^{6}$, Ilias Cagiannos, MD, FRCSC ${ }^{1,2}$; Christopher Morash, MD, FRCSC ${ }^{1,2}$; Luke T. Lavallée, MDCM, MSc, FRCSC ${ }^{1,2}$ ${ }^{1}$ Division of Urology, University of Ottawa, Ottawa, ON, Canada; ${ }^{2}$ Ottawa Hospital Research Institute, University of Ottawa, Ottawa, ON, Canada; ${ }^{3}$ School of Nursing, University of Ottawa, Ottawa, ON, Canada; ${ }^{4}$ Departments of Surgery (Urology) and Surgical Oncology, Princess Margaret Cancer Centre, University Health Network and the University of

Toronto, Toronto, ON, Canada; ${ }^{5}$ Departments of Health Research Methods Evidence and Impact and Surgery, McMaster University, Hamilton, ON, Canada; ${ }^{6}$ Division of Urology, University of Sherbrooke, Sherbrooke, QC, Canada

Funding: This study was supported by Kidney Cancer Research Network of Canada, Canadian Urologic Oncology Group, Canadian Urology Association Scholarship Foundation, International Kidney Cancer Coalition, and The Ottawa Hospital Academic Medical Organization

Cite as: Can Urol Assoc J 2020 June 16; Epub ahead of print. http://dx.doi.org/10.5489/cuaj.6575

Published online June 16, 2020

$* * *$

\section{Abstract}

Introduction: Shared decision-making incorporates patient's values and preferences to achieve highquality decisions. The objective of this study was to develop an acceptable patient decision aid to facilitate shared decision-making for the management of small renal masses (SRMs).

Methods: The International Patient Decision Aids Standards were used to guide an evidence-based development process. Management options included active surveillance, thermal ablation, partial nephrectomy, and radical nephrectomy. A literature review was performed to provide incidence rates for outcomes of each option. Once a prototype was complete, alpha-testing was performed using a 10-question survey to assess acceptability with patients, patient advocates, urologists, and methodological experts. The primary outcome was acceptability of the decision aid.

Results: A novel patient decision aid was created to facilitate shared decision-making for the management of SRMs. Acceptability testing was performed with 20 patients, 10 urologists, two patient advocates, and one methodological expert. Responders indicated the decision aid was appropriate in length $(82 \%, 27$ of 33), well-balanced $(82 \%, 27$ of 33$)$, and had language that was easy to follow $(94 \%, 31$ of 33$)$. All patient responders felt the decision aid would have been helpful during 
their consultation and would recommend the decision aid for future patients (100\%, 20 of 20). Most urologists reported they intend to use the decision aid (90\%, 9 of 10$)$.

Conclusions: A novel patient decision aid was created to facilitate shared decision-making for management of SRMs. This clinical tool was acceptable with patients, patient advocates, and urologists and is freely available at: https://decisionaid.ohri.ca/decaids.html.

\section{Introduction}

Small renal masses (SRMs) are typically defined as solid lesions in the kidney measuring $<4 \mathrm{~cm}$. Surgical removal, active surveillance, and thermal ablation each provide excellent short term cancerspecific survival (all $>90 \%$ over 5 years) yet vary significantly in their short term and long term risks and benefits. ${ }^{1-3}$ The choice for which management option is best for a specific patient depends on patient factors, tumour characteristics, surgeon factors, and patient's values and preferences.

When several management options are available, patients should be encouraged to weigh the risks and benefits across options and to determine their values when deciding on a treatment option. ${ }^{2}$ Studies have shown that high-quality decisions can be achieved when patients are encouraged to clarify and communicate their values, and have the opportunity to determine which management option best matches their individual preferences. ${ }^{4}$

Patient decision aids (PtDAs) are clinical tools that facilitate shared decision-making for a population of patients facing a challenging decision. At a minimum, a PtDA must explain the decision to be made, present the available management options (including risks and benefits) and help patients communicate their values and preferences. ${ }^{5}$ A systematic review of over 100 PtDA trials showed improved knowledge, more realistic expectations, lower decisional conflict and higher participation compared to usual care. ${ }^{5}$ The objective of this study was to create a novel, evidencebased PtDA for the management of SRMs and to assess the PtDA for acceptability with patients, patient advocates, urologists, and methodological experts.

\section{Methods}

Institutional ethics board approval was obtained (OHSN-REB 20170729-01H). The International Patient Decision Aids Standards were used to guide the systematic development of the PtDA. ${ }^{4}$ The International Patient Decision Aids Standards are a set of criteria that were agreed upon by shared decision-making experts to standardize the development, implementation and evaluation of highquality PtDAs. ${ }^{4}$ The Ottawa Decision Support Framework was used to guide the evidence-based approach to our PtDA development. ${ }^{6}$

We have previously published the process for developing a high-quality PtDA (Figure 1). ${ }^{7,8}$ The structured process includes: a) needs assessment for decisional support, b) formation of a 
steering committee, c) literature review, d) determining management options and outcomes to include, e) creation of PtDA prototype, $\mathrm{f}$ ) acceptability testing (alpha testing), f) updating PtDA with feedback from alpha testing to create final product, g) validation testing. ${ }^{7-9}$

\section{Needs assessment}

A previous survey of kidney cancer experts highlighted the development of decisional tools for kidney cancer patients as one of the top 10 priorities for kidney cancer research. ${ }^{10}$ Surveys of patients who have previously been treated for kidney tumours show the majority of patients and caregivers report inadequate resources for patients. ${ }^{11}$ These studies confirmed the need for a PtDA to support the decision for management of SRMs.

\section{Creation of steering committee}

A steering committee was assembled that included content and process experts. Content experts included 5 academic urologic oncologists. Process experts included an international leader in the development and evaluation of PtDAs, a urology resident, and a research assistant. In addition, feedback was solicited from kidney cancer patients and patient advocacy groups to inform the committee of perceived resource gaps and topics of interest for inclusion.

\section{Literature review for management options and outcomes}

A thorough literature review was performed to determine the best available evidence for management of SRMs. Medline, EMBASE and Ovid databases were searched. Current practice guidelines from urological associations were referenced and sources cited were reviewed. ${ }^{12-14}$ The literature was searched for the highest quality of evidence on outcomes for each management option. Once the literature review was completed, the management options and outcomes were discussed by the steering committee until consensus was reached.

\section{Alpha testing}

A prototype of the PtDA was created and alpha testing was performed to assess the acceptability. Stakeholders including patients, urologists, patient advocates, and methodological experts were invited to review the PtDA prototype and complete the alpha testing. Patient responders were individuals who had previously faced the decision regarding management of a SRM. Urologists were individuals who routinely see patients with SRMs in consultation, provide counseling and perform/order all the proposed management options. Patient advocates were representatives from kidney cancer organizations who are highly involved in patient advocacy. Finally, methodological experts were individuals with an advanced degree in the study of shared decision-making.

Alpha testing was performed by inviting individuals to review the PtDA and answer a 10question survey which was based on a validated acceptability scoring system (Appendix 1). ${ }^{15}$ Patients completed the survey at the end of their routine urology follow-up clinic appointment. Urologists, patient advocates and methodological experts completed an online survey after reviewing the PtDA prototype. 
Survey results were analyzed with descriptive analyses. All feedback provided was reviewed by the steering committee and used to update the PtDA prototype to create a final product. We intended for the PtDA to be used as a handout after or in conjunction with a patient's initial consultation with their urologist. This would allow patients to understand the context of the decision and would provide time to allow clarification of their personal preferences and values before a decision was made.

\section{Results}

Following the International Patient Decision Aids Standards, an evidence-based PtDA was created.

\section{Literature review}

The literature review revealed 3 current practice guidelines on the management of localized renal masses. ${ }^{12-14}$ There were 5 systematic reviews and meta-analyses, 1 randomized controlled trial, 2 prospective cohorts and several retrospective studies that reported data relevant to the PtDA. ${ }^{1,3,16-26}$ Summary of evidence tables were created to synthesize the data (Supplementary Table 1).

\section{Patient decision aid prototype}

Following the literature review, a prototype of the PtDA was created. The PtDA specifically indicated that a decision needs to be made. The management options included were active surveillance, thermal ablation, minimally-invasive (laparoscopic, robotic) partial nephrectomy, open partial nephrectomy and minimally-invasive radical nephrectomy. Open radical nephrectomy was not included as an option as it is invasive and is not standard of care for the management of SRMs. ${ }^{12}$ Information regarding the role of renal mass biopsy was included to provide patient education on this component of SRM management. While the results of a renal mass biopsy may be important and influence management decisions for SRMs, this PtDA does not explicitly address whether or not to have a renal mass biopsy because decision aids are designed to address one decision. The steering committee viewed the decision to perform a biopsy as separate from management of the SRM because many patients may be managed without having a biopsy. For example, some patients may select surveillance without a biopsy if the mass is small or they have competing risks. The PtDA does educate patients about renal mass biopsy and encourages them to discuss this topic with their urologist.

The benefits included on the PtDA were cancer-specific survival at 5 years, disease-free survival at 5 years, and length of hospital stay. Harms included were probability of metastases at 5 years, major complications from treatment (Clavien Dindo grade III - IV), post-treatment urine leak, post-treatment bleeding, rates of renal replacement therapy at 5 years, expected incisions, and probability of flank bulge. Outcomes were presented using pictorial diagrams (Figure 2). For clarification of values, patients were instructed to rate the importance of each outcome on a scale from 0 to 5 . The use of diagrams, consistent figures and simple language were used to facilitate understanding by patients of various levels of health literacy. Language was targeted at an eighthgrade reading level (SMOG readability level 8.1, grade 8). 
The final PtDA prototype was 23 pages (Appendix 2). All 6 International Patient Decision Aid Standards qualifying criteria were met, as were all 6 certification criteria. ${ }^{27}$ The prototype met 21 of 23 quality criteria with the two missing criteria pertaining to validation testing (Table 1). This PtDA was based on the Ottawa Decision Support Framework approach that has been tested in over 20 randomized controlled trials. ${ }^{28}$

\section{Alpha testing}

Alpha testing was completed by 20 patients, 10 urologists, 2 kidney cancer patient advocates, and 1 methodological expert. All responders completed the entire 10 question survey and had an opportunity to provide additional narrative feedback.

The length of the decision aid was felt to be appropriate by $82 \%$ of responders ( 27 of 33 ). The majority of responders reported that the language was easy to follow (94\%, 31 of 33) and most felt the presentation of management options was well balanced $(82 \%, 27$ of 33). All responding patients felt the PtDA would have been a valuable tool during their decision-making process $(100 \%, 20$ of 20$)$ and would recommend this PtDA for future patients referred with a SRM (100\%, 20 of 20). Most responding urologists intend to use this PtDA in their practice $(90 \%, 9$ of 10$)$.

Narrative feedback from responders highlighted several important strengths of the PtDA. Consistently, responders commented on the PtDA filling an unmet gap in the resources for patients with a SRM. Other strengths included the diagrams, thoroughness, and clarity. Patient advocates had suggestions with regards to sequencing of the information to ensure the PtDA was patient-centred. For example, the explanation of a biopsy was suggested to precede the presentation of management options.

\section{Creation of final patient decision aid and dissemination}

The results of the alpha testing were reviewed by the steering committee and used to update the PtDA prototype. Once the PtDA was revised and agreed upon by the steering committee, the final version was made freely available on our institutions' research website and included in the international A to $\mathrm{Z}$ inventory of PtDAs: https://decisionaid.ohri.ca/decaids.html.

\section{Discussion}

In this study, we developed a PtDA to facilitate shared decision-making for the management of SRMs following the International Patient Decision Aid Standards. Alpha testing confirmed high acceptability of the PtDA among patients and urologists. In fact, 100\% of patients and urologists found the PtDA to be valuable for guiding the decision-making process with $90 \%$ of urologists reporting they would use the tool in their clinic. It is anticipated that use of this PtDA would improve patient satisfaction with care.

This study describes the evidence-based development process and acceptability testing of a novel PtDA for the management of SRMs. PtDA use improves patients' knowledge of their health condition and satisfaction in the decision-making process. ${ }^{5}$ PtDAs also decrease patients' decisional conflict and indecisiveness. ${ }^{5}$ In 2015, a panel of kidney cancer experts and patient-partner advocates 
highlighted the lack of decisional supports for patients with kidney cancer, and appealed for the development of these tools as one of the top 10 priorities in kidney cancer research. ${ }^{10,29}$ To directly address this call for action, we followed an evidence-based process to develop a PtDA for the management of SRMs. This tool was found to be acceptable and valued by key stakeholders including patients, urologists, patient advocates and methodological experts. Importantly, several international kidney cancer patient-centred organizations have reviewed this PtDA and intend to facilitate dissemination internationally. While these groups provided feedback, the PtDA was created free of commercial bias following a rigorous and standardized process.

Patients with a SRM are optimally positioned to benefit from a PtDA. The management options provide comparable short-term cancer control, yet vary significantly in their risks and benefits. Where active surveillance avoids surgery and its associated risks, patients may find this approach anxiety-provoking as the renal mass remains in situ. Furthermore, long periods of follow up may impose a burden on some patients who place more value on definitive care. Surgical removal, on the other hand, usually results in cure, yet, patients are exposed to the risks associated with surgery and anesthesia, as well as long term risk of decreased renal function. Thermal ablation, may provide definitive treatment with less risk of complications, but is supported by less evidence for long term cancer control.

Importantly, most patients with a SRM have time to consider their management options, review the risks and benefits and clarify their values and preferences. Thus, the use of a PtDA for the management of SRMs allows for high-quality decisions for these individuals facing a preferencesensitive decision. ${ }^{30}$ Additionally, this clinical tool provides information for all patients with a SRM regarding the range of management options in a patient-centred format regardless of what options are recommended/available for them. Improving patients' knowledge of their health condition provides patient education and may empower patients to seek clarification and/or a second opinion to ensure the treatment they receive meets the standard of care and aligns with their values. There are few patient decision aids available that address urologic decisions and most that are available are for prostate cancer screening or treatment of localized prostate cancer. ${ }^{5}$ This paper provides the framework necessary for researchers to create similar tools to expand the availability of PtDAs in urologic practice.

The management of SRMs is a common and challenging decision faced by patients and urologists around the world. This PtDA was designed to apply to a broad audience, therefore the management options included on the PtDA are based on the best available evidence from the international literature. For example, the inclusion of a minimally invasive radical nephrectomy was included as a management option, because in many parts of the world, this would be an option offered and many patients searching for information online may read about this option. We included a page on the PtDA for urologists to indicate to their patients, what options are available and recommended for them to ensure patients are not misled about the management options they have to choose between. Additionally, the outcomes that were included on the PtDA were chosen as they 
were felt to be patient-important outcomes and were reviewed and updated by the kidney cancer patient-advocates. Finally, information was included on the role of renal mass biopsy, however biopsy was not included as a management option because it is a diagnostic test used to inform the decision between management options. Decision aid methodology suggests that a PtDA should focus on one decision. Hence, the choice of whether to pursue a renal mass biopsy or not could be the topic of a separate PtDA.

There are several strengths of this study. First, the development of a PtDA for the management of SRMs fills an unmet resource for patients and urologists that has been highlighted as a top priority in kidney cancer research. ${ }^{10}$ Second, the inclusion of several groups of stakeholders provided input and feedback from individuals with various expertise and vantage points. Finally, the PtDA directly responds to a call for decisional supports for patients with kidney cancer and their caregivers. There are some limitations to the study. We did not include community-based urologists in the steering committee or alpha testing. It is possible their practice varies from an academic setting and is not represented by this tool. Second, the outcomes included on the PtDA represent the best available evidence at this time. As further evidence becomes available, the PtDA will need to be updated. This is a known component of maintaining high quality PtDAs. Finally, patients and kidney cancer patient advocates provided feedback regarding the format and content during the PtDA development. However, the lack of patient involvement at the initial step of PtDA design is a limitation.

\section{Conclusions}

We have developed a novel PtDA to facilitate shared decision-making for the management of SRMs. This PtDA was acceptable and valued by patients and urologists and meets a significant gap in the resources available for patients. The PtDA is freely available at:

https://decisionaid.ohri.ca/decaids.html. 


\section{References}

1. Katsanos K, Mailli L, Krokidis M, McGrath A, Sabharwal T, Adam A. Systematic review and meta-analysis of thermal ablation versus surgical nephrectomy for small renal tumours. Cardiovasc Intervent Radiol. 2014;37(2):427-437. doi:10.1007/s00270-014-0846-9.

2. Pierorazio M, Johnson, MH PH, Sozio S, et al. Management of Renal Masses and Localized Renal Cancer. Comp Eff Rev. 2016; Review No.

3. Jewett MAS, Mattar K, Basiuk J, et al. Active surveillance of small renal masses: Progression patterns of early stage kidney cancer. Eur Urol. 2011;60(1):39-44. doi:10.1016/j.eururo.2011.03.030.

4. Elwyn G, O’Connor A, Stacey D, et al. International Patient Decision Aids Standards (IPDAS) Collaboration. Developing a quality criteria framework for patient decision aid: online international Delphi consensus process. Br Med J. 2006. doi:10.1136/bmj.38926.629329.AE <http://dx.doi.org/10.1136/bmj.38926.629329.AE > file $<$ http://orca.cf.ac.uk/538/1/Developing_a_quality.pdf $>$.

5. Stacey D, Légaré F, Lewis K, et al. Decision aids for people facing health treatment or screening decisions ( Review ). Cochrane Collab. 2017;(4).

doi:10.1002/14651858.CD001431.pub5.www.cochranelibrary.com.

6. Legare F, O'Connor AM, Graham ID, Wells GA, Tremblay S. Impact of the Ottawa Decision Support Framework on the agreement and the difference between patients' and physicians' decisional conflict. Med Decis Mak. 2006;26(4):373-390. doi:10.1177/0272989X06290492.

7. McAlpine K, Breau RH, Stacey D, et al. Development and acceptability testing of a patient decision aid for individuals with localized renal masses considering surgical removal with partial or radical nephrectomy. Urol Oncol Semin Orig Investig. 2019;37(11):811.e1-811.e7. doi:10.1016/j.urolonc.2019.08.014.

8. McAlpine K, Lavallée LT, Stacey D, et al. Development and acceptability testing of a patient decision aid for urinary diversion with radical cystectomy. J Urol. 2019. doi:10.1097/ju.0000000000000341.

9. Coulter A, Stilwell D, Kryworuchko J, Mullen PD, Ng CJ. A systematic development process for patient decision aids. BMC Med Infrom Decis Mak. 2013;13(Suppl 2).

10. Jones J, Bhatt J, Avery J, et al. The kidney cancer research priority-setting partnership: Identifying the top 10 research priorities as defined by patients, caregivers, and expert clinicians. CUAJ. 2017.

11. Russo P, Szczech LA, Torres GS, Swartz MD. Patient and Caregiver Knowledge and Utilization of Partial Versus Radical Nephrectomy : Results of a National Kidney Foundation Survey to Assess Educational Needs of Kidney. Am J Kidney Dis. 2013;61(6):939-946. doi:10.1053/j.ajkd.2013.01.028.

12. Jewett MAS, Rendon R, Lacombe L, et al. Canadian guidelines for the management of small renal masses (SRM). J Can Urol Assoc. 2015;9(6):160-163. doi:10.5489/cuaj.2969.

13. Campbell S, Uzzo RG, Allaf ME, et al. Renal Mass and Localized Renal Cancer: AUA Guideline. J Urol. 2017;S0022-5347(17):59870-59875.

14. Ljungberg B, Albiges L, Bensalah K, et al. EAU Guidelines on Renal Cell Carcinoma 2018. Euro Urol. 2018;29(5):451-458. 
15. O’Connor A, A C. Acceptability. Ottawa Ottawa Hosp Res Inst. 1996;modified 2:5p.

16. Ma Y, Bedir S, Cadeddu JA, Gahan JC. Long-term outcomes in healthy adults after radiofrequency ablation of T1 a renal tumours. BJU Int. 2014;113(1):51-55. doi:10.1111/bju.12366.

17. Park BK, Gong IH, Kang MY, et al. RFA versus robotic partial nephrectomy for T1a renal cell carcinoma: a propensity score-matched comparison of mid-term outcome. European Radiology. 2018:1-7.

18. Pierorazio PM, Johnson MH, Ball MW, et al. Five-year Analysis of a Multi-institutional Prospective Clinical Trial of Delayed Intervention and Surveillance for Small Renal Masses: The DISSRM Registry. Eur Urol. 2015;68(3):408-415. doi:10.1016/j.eururo.2015.02.001.

19. Thompson RH, Atwell T, Schmit G, et al. Comparison of partial nephrectomy and percutaneous ablation for cT1 renal masses. Eur Urol. 2015;67(2):252-259. doi:10.1016/j.eururo.2014.07.021.

20. Tsai S-H, Tseng P-T, Sherer BA, et al. Open versus robotic partial nephrectomy: Systematic review and meta-analysis of contemporary studies. Int J Med Robot Comput Assist Surg. 2018;(January):e1963. doi:10.1002/rcs.1963.

21. Patel HD, Pierorazio PM, Johnson MH, et al. Renal functional outcomes after surgery, ablation, and active surveillance of localized renal tumors: A systematic review and metaanalysis. Clin J Am Soc Nephrol. 2017;12(7):1057-1069. doi:10.2215/CJN.11941116.

22. Van Poppel H, Da L, Albrecht W, et al. A Prospective, Randomised EORTC Intergroup Phase 3 Study Comparing the Oncologic Outcome of Elective Nephron-Sparing Surgery and Radical Nephrectomy for Low-Stage Renal Cell Carcinoma. Eur Urol. 2011;59(4):543-552. doi:10.1016/j.eururo.2010.12.013.

23. Van Poppel H, Da Pozzo L, Albrecht W, et al. A Prospective Randomized EORTC Intergroup Phase 3 Study Comparing the Complications of Elective Nephron-Sparing Surgery and Radical Nephrectomy for Low-Stage Renal Cell Carcinoma \{A figure is presented\}. Eur Urol. 2007;51(6):1606-1615. doi:10.1016/j.eururo.2006.11.013.

24. Potretzke AM, Knight BA, Zargar H, et al. Urinary fistula after robot-assisted partial nephrectomy: A multicentre analysis of 1791 patients. BJU Int. 2016;117(1):131-137. doi:10.1111/bju.13249.

25. Richard PO, Jewett MAS, Tanguay S, et al. Safety, reliability and accuracy of small renal tumour biopsies: results from a multi-institution registry. BJU Int. 2017;119(4):543-549. doi:10.1111/bju.13630.

26. Marconi L, Dabestani S, Lam TB, et al. Systematic review and meta-analysis of diagnostic accuracy of percutaneous renal tumour biopsy. Eur Urol. 2016;69(4):660-673. doi:10.1016/j.eururo.2015.07.072.

27. Joseph-Williams N, Newcombe R, Politi M, et al. Toward Minimum Standards for Certifying Patient Decision Aids. Med Decis Mak. 2014;34(6):699-710. doi:10.1177/0272989x13501721.

28. Stacey D, Boland L, Garvelink M, et al. 20th Anniversary Update of the Ottawa Decision Support Framework: A Workshop to Discuss Evidence, Lessons Learned, and Future Research. In: Quebec City, QC; 2019:3.

29. Cowan K. The James Lind Alliance. J Ambul Care Manage. 2010;33(3):241-248. doi:10.1097/jac.0b013e3181e62cda. 
30. Fagerlin A, Pignone M, Abhyankar P, et al. Clarifying values: an updated review. BMC Med Inf Decis Mak. 2013;13 Suppl 2(Suppl 2):S8. doi:10.1186/1472-6947-13-S2-S8. 


\section{Figures and Tables}

Fig. 1. Development process of patient decision aid. Recreated from Coulter et al (2013). ${ }^{9}$

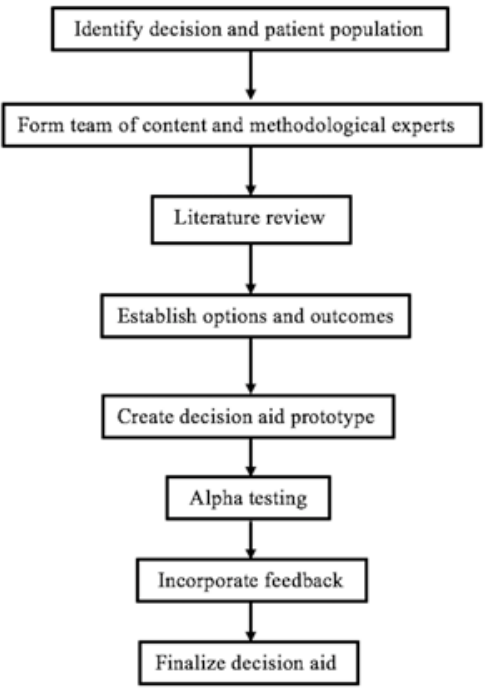

Fig. 2. Pictorial representation of outcomes. This diagram presents the rates of post-treatment bleeding for each treatment option.
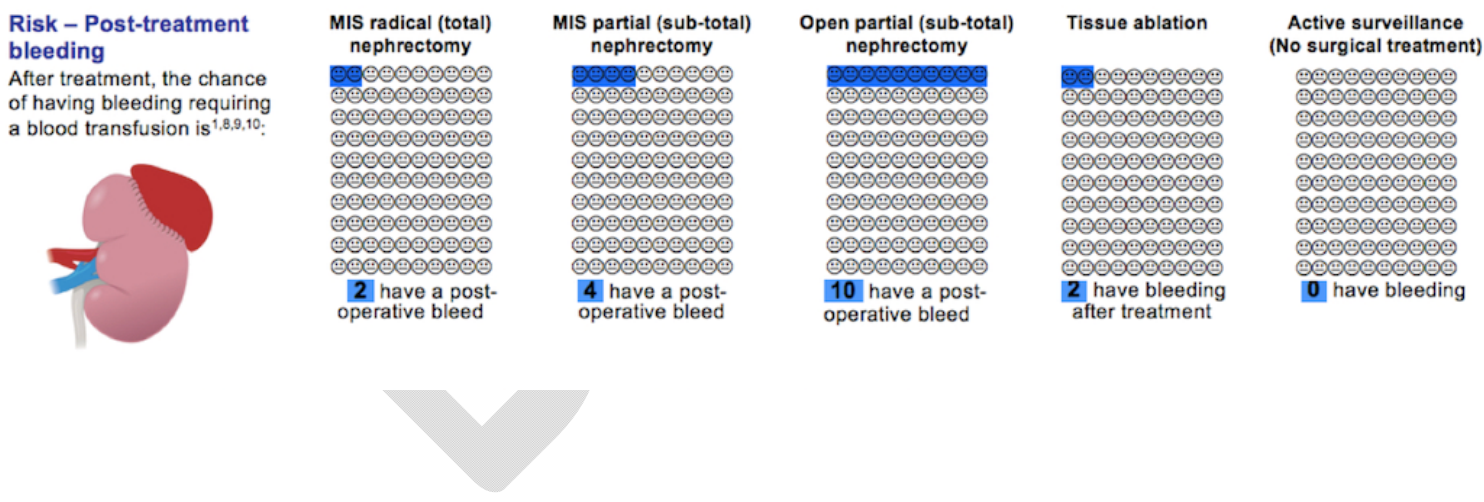


\begin{tabular}{|c|c|c|c|}
\hline Item dimension & Qualifying criteria & Certification criteria & Quality criteria \\
\hline \multirow[t]{5}{*}{ Information } & $\begin{array}{l}\text { Describes the health condition } \\
\text { or problem for which decision } \\
\text { is required }\end{array}$ & $\begin{array}{l}\text { Shows the negative and positive } \\
\text { features of options with equal } \\
\text { detail }\end{array}$ & $\begin{array}{l}\text { Describes the natural course of } \\
\text { the health condition or problem } \\
\text { if no action is taken }\end{array}$ \\
\hline & $\begin{array}{l}\text { Explicitly states decision that } \\
\text { needs to be considered }\end{array}$ & & $\begin{array}{l}\text { Makes it possible to compare the } \\
\text { positive and negative features of } \\
\text { available options }\end{array}$ \\
\hline & $\begin{array}{l}\text { Describes the options available } \\
\text { for the index decision }\end{array}$ & & \\
\hline & $\begin{array}{c}\text { Describes positive features of } \\
\text { each option }\end{array}$ & & \\
\hline & $\begin{array}{c}\text { Describes negative features of } \\
\text { each option }\end{array}$ & & \\
\hline \multirow[t]{4}{*}{ Probabilities } & & & $\begin{array}{c}\text { Provides information about } \\
\text { outcome probabilities associated } \\
\text { with the options }\end{array}$ \\
\hline & & & $\begin{array}{l}\text { Specifies the defined group of } \\
\text { patients for whom the outcome } \\
\text { probabilities apply }\end{array}$ \\
\hline & & & $\begin{array}{c}\text { Specifies the event rates for } \\
\text { outcome probabilities }\end{array}$ \\
\hline & & & $\begin{array}{l}\text { Allows the user to compare } \\
\text { outcome probabilities across } \\
\text { options using the same time } \\
\text { period }\end{array}$ \\
\hline
\end{tabular}


Shared decision-making in the management of small renal masses

\begin{tabular}{|c|c|c|}
\hline & & $\begin{array}{l}\text { Allows the user to compare } \\
\text { outcome probabilities across the } \\
\text { same denominator }\end{array}$ \\
\hline & & $\begin{array}{l}\text { Provides more than } 1 \text { way of } \\
\text { viewing the probabilities (e.g., } \\
\text { words, numbers, diagrams) }\end{array}$ \\
\hline Values & $\begin{array}{l}\text { Describes what it is like to } \\
\text { experience consequence of the } \\
\text { options. }\end{array}$ & $\begin{array}{c}\text { Asks patients to think about } \\
\text { which positive and negative } \\
\text { features of options matter most } \\
\text { to them }\end{array}$ \\
\hline \multirow[t]{2}{*}{ Guidance } & & $\begin{array}{c}\text { Provides a step-by-step way to } \\
\text { make a decision }\end{array}$ \\
\hline & & $\begin{array}{l}\text { Includes tools like worksheets or } \\
\text { lists of questions to use when } \\
\text { discussing options with a } \\
\text { practitioner }\end{array}$ \\
\hline \multirow[t]{4}{*}{ Development } & & $\begin{array}{l}\text { Development process included a } \\
\text { needs assessment with clients or } \\
\text { patients }\end{array}$ \\
\hline & & $\begin{array}{l}\text { Development process included a } \\
\text { needs assessment with health } \\
\text { professionals }\end{array}$ \\
\hline & & $\begin{array}{l}\text { Development process included } \\
\text { review by clients/patients not } \\
\text { involved in producing the } \\
\text { decision support intervention }\end{array}$ \\
\hline & & $\begin{array}{l}\text { Development process included } \\
\text { review by professionals not } \\
\text { involved in producing the } \\
\text { decision support intervention }\end{array}$ \\
\hline
\end{tabular}


Shared decision-making in the management of small renal masses

\begin{tabular}{|c|c|c|}
\hline & & $\begin{array}{l}\text { Field tested with patients who } \\
\text { were facing the decision. }\end{array}$ \\
\hline & & $\begin{array}{l}\text { Field tested with practitioners } \\
\text { who counsel patients who face } \\
\text { the decision }\end{array}$ \\
\hline \multirow[t]{4}{*}{ Evidence } & $\begin{array}{l}\text { Provides citations to the } \\
\text { evidence selected }\end{array}$ & $\begin{array}{c}\text { Describes how research } \\
\text { evidence was selected or } \\
\text { synthesized }\end{array}$ \\
\hline & $\begin{array}{l}\text { Provides a production or } \\
\text { publication date }\end{array}$ & $\begin{array}{l}\text { Describes the quality of the } \\
\text { research evidence used }\end{array}$ \\
\hline & $\begin{array}{l}\text { Provides information about the } \\
\text { update policy }\end{array}$ & \\
\hline & $\begin{array}{l}\text { Provides information about the } \\
\text { levels of uncertainty around the } \\
\text { event or outcome probabilities }\end{array}$ & \\
\hline Disclosure & $\begin{array}{l}\text { Provides information about the } \\
\text { funding source used for } \\
\text { development }\end{array}$ & $\begin{array}{l}\text { Includes authors'/developers' } \\
\text { credentials or qualifications }\end{array}$ \\
\hline Plain language & $\sqrt{2}$ & Reports readability levels \\
\hline \multirow[t]{2}{*}{ Evaluation } & \multirow[t]{2}{*}{$\begin{array}{l}\text { Describes what the test is } \\
\text { designed to measure }\end{array}$} & $\begin{array}{c}\text { Evidence improved match } \\
\text { between preferences of the } \\
\text { informed patient and the option } \\
\text { chosen }\end{array}$ \\
\hline & & $\begin{array}{l}\text { Evidence patient decision aid } \\
\text { helps patients improve their } \\
\text { knowledge about options' } \\
\text { features }\end{array}$ \\
\hline
\end{tabular}


Shared decision-making in the management of small renal masses

\begin{tabular}{|c|c|c|c|c|c|c|c|}
\hline \multicolumn{7}{|c|}{ Supplementary Table 1. Treatment of small renal masses: Summary of evidence } & 1A. Perioperative \\
\hline \multicolumn{4}{|c|}{ Study characteristics } & \multicolumn{2}{|l|}{ 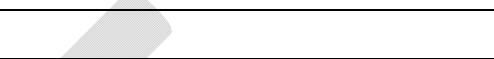 } & \multicolumn{2}{|c|}{ Outcomes } \\
\hline Author & Population & Year & Type of study & $\begin{array}{c}\text { Followup } \\
\text { (mo) }\end{array}$ & Renal bleed & Urine leak & $\begin{array}{l}\text { Overall rate of } \\
\text { complications }\end{array}$ \\
\hline $\mathrm{Ma}^{1}$ & T1a; RFA; $n=52$ & 2014 & Retrospective review & 60 & - & - & - \\
\hline Katsanos $^{2}$ & $\begin{array}{c}\text { T1a; RFA vs RN; } \\
n=587\end{array}$ & 2014 & Meta-analysis & 60 & - & - & $\begin{array}{l}\text { RFA } 7.4 \% \\
\text { RN } 11 \%\end{array}$ \\
\hline Bahouth $^{3}$ & $\begin{array}{c}\text { T1a } \\
\text { Surveillance; } \mathrm{n}=70\end{array}$ & 2015 & Retrospective review & 34 & 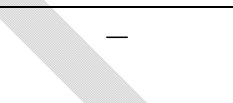 & - & - \\
\hline Olweny $^{4}$ & $\begin{array}{l}\text { T1a; } n=74 \\
\text { RFA vs. PN }\end{array}$ & 2012 & Retrospective review & 72 & - & - & - \\
\hline Chang $^{5}$ & $\begin{array}{c}\text { T1a; } n=90 \\
\text { RFA vs. PN }\end{array}$ & 2015 & Retrospective review & 60 & $\begin{array}{l}\text { Blood loss: } \\
\text { RFA: } 75 \mathrm{ml} \\
\text { PN: } 243 \mathrm{ml}\end{array}$ & - & $\begin{array}{c}\text { Major } \\
\text { complications: } \\
\text { RFA: } 2.2 \% \\
\text { PN: } 4.4 \%\end{array}$ \\
\hline Park $^{6}$ & $\begin{array}{l}\text { T1a; } n=126 \\
\text { RFA vs. RPN }\end{array}$ & 2018 & Retrospective review & 24 & - & - & $\begin{array}{l}\text { PN: } 5 \% \\
\text { RFA: } 5 \%\end{array}$ \\
\hline Pierorazio $^{7}$ & $\begin{array}{c}\text { T1a; } n=497 \\
\text { AS vs. PI }\end{array}$ & 2015 & Prospective cohort & 25 & - & - & - \\
\hline Jewett $^{8}$ & $\mathrm{~T} 1 \mathrm{a} ; \mathrm{AS} ; \mathrm{n}=178$ & 2011 & Prospective cohort & 28 & - & - & - \\
\hline Klatte $^{9}$ & $\begin{array}{c}\text { T1a; } n=1191 ; P N \text { vs } \\
\text { CA }\end{array}$ & 2014 & Meta-analysis & 26 & $\begin{array}{l}\text { PN: } 8.4 \% \\
\text { CA: } 4.9 \%\end{array}$ & $\begin{array}{c}\text { PN: } 3 \% \\
\text { CA: } 0.4 \%\end{array}$ & $\begin{array}{l}\text { PN: } 22 \% \\
\text { CA: } 10 \%\end{array}$ \\
\hline Gervais $^{10}$ & T1a-T2; n=85; RFA & 2005 & Retrospective review & 27 & RFA: $6 \%$ & RFA: $1 \%$ & RFA: $10 \%$ \\
\hline Whitson $^{11}$ & $\begin{array}{l}\text { T1a; } \mathrm{n}=8818 ; \mathrm{RFA} \\
\text { or CA vs. PN }\end{array}$ & 2012 & Retrospective review & 34 & - & - & - \\
\hline Pavlovich $^{12}$ & T1a; $n=21 ;$ RFA & 2002 & Retrospective review & 2 & RFA: $5 \%$ & RFA: $0 \%$ & $\begin{array}{l}\text { Minor: } 19 \% \\
\text { Major: } 0 \%\end{array}$ \\
\hline Thompson $^{13}$ & $\begin{array}{c}\text { cT1; } n=1424 ; \text { CA vs. } \\
\text { RFA vs. PN }\end{array}$ & 2015 & Retrospective review & 35 & - & - & - \\
\hline
\end{tabular}


Shared decision-making in the management of small renal masses

\begin{tabular}{|c|c|c|c|c|c|c|c|}
\hline Maurice $^{14}$ & $\begin{array}{c}\text { T1; } n=411 \\
\text { OPN vs. RAPN }\end{array}$ & 2017 & Retrospective review & 6 & $\begin{array}{l}\text { RAPN: } 1.3 \% \\
\text { OPN: } 2 \%\end{array}$ & $\begin{array}{l}\text { RAPN: } 0 \% \\
\text { OPN: } 2 \%\end{array}$ & $\begin{array}{c}\text { RAPN: } 20 \% \\
\text { OPN: } 36 \%\end{array}$ \\
\hline Pierorazio $^{15}$ & $\begin{array}{c}\text { T1-2; RFA or CA vs. } \\
\text { PN vs. RN }\end{array}$ & 2016 & $\begin{array}{c}\text { Comparative } \\
\text { effectiveness review }\end{array}$ & & $\begin{array}{l}\text { RN: } 2-7 \% \\
\text { PN: } 2-16 \% \\
\text { RFA: } 0-5 \%\end{array}$ & $\begin{array}{c}\text { RN: } 0 \% \\
\text { PN: } 2.6 \% \\
\text { RFA: } 0-4 \%\end{array}$ & $\begin{array}{c}\text { Major } \\
\text { complications: } \\
\text { RN: } 3 \% \\
\text { PN: } 6-25 \% \\
\text { RFA: } 6 \% \\
\end{array}$ \\
\hline Young $^{16}$ & T1; RFA; $n=298$ & 2012 & Retrospective review & 20 & RFA: $1 \%$ & RFA: $1.5 \%$ & RFA: $29 \%$ \\
\hline Tsai $^{17}$ & $\begin{array}{c}\text { T1; n=9906; } \\
\text { OPN vs. RAPN }\end{array}$ & 2018 & Meta-analysis & $\begin{array}{c}\text { No absolute } \\
\text { values } \\
\text { reported }\end{array}$ & $\begin{array}{c}\text { No absolute } \\
\text { values reported }\end{array}$ & $\begin{array}{c}\text { No absolute } \\
\text { values reported }\end{array}$ & $\begin{array}{c}\text { No absolute values } \\
\text { reported }\end{array}$ \\
\hline Patel $^{18}$ & $\begin{array}{c}\text { T1-2; RN vs. PN vs. } \\
\text { RFA vs. AS }\end{array}$ & 2017 & Meta-analysis & 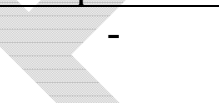 & - & - & - \\
\hline Van Poppel ${ }^{19-21}$ & $\begin{array}{l}\text { T1-T2; } \mathrm{n}=541 ; \\
\text { RN vs. PN }\end{array}$ & $\begin{array}{l}2007 \\
2011\end{array}$ & D & 112 & $\begin{array}{c}\text { Hemorrhage: } \\
\text { RN: } 1.2 \% \\
\text { PN: } 3.1 \% \\
\end{array}$ & $\begin{array}{c}\text { RN: } 0 \% \\
\text { PN: } 4.4 \%\end{array}$ & $\begin{array}{c}\text { Reoperation rate: } \\
\text { RN: } 2 \% \\
\text { PN: } 4 \%\end{array}$ \\
\hline Potretzke $^{22}$ & $\mathrm{~T} 1-\mathrm{T} 4$ & 2016 & $\begin{array}{l}\text { Retrospective review } \\
\text { Literature review }\end{array}$ & - & - & $\begin{array}{c}\text { Retrospective: } \\
\text { RAPN: } 0.8 \% \\
\text { Literature: } \\
\text { OPN: } 1-11.8 \% \\
\text { RAPN: } 0.8-3 \% \\
\text { LPN: } 1.9-16.5 \%\end{array}$ & - \\
\hline
\end{tabular}

AUA: American Urology Association; CA: cryoablation; mo: months; OPN: open partial nephrectomy; PN: partial nephrectomy; RCT: randomized controlled trial; RAPN: robotic assisted partial nephrectomy; RFA: radiofrequency ablation; RN: radical nephrectomy; -: do not report own data. 
Shared decision-making in the management of small renal masses

\begin{tabular}{|c|c|c|c|c|c|c|c|c|c|c|}
\hline \multicolumn{11}{|c|}{ 1B. Long term outcomes } \\
\hline \multicolumn{5}{|c|}{ Study characteristics } & \multicolumn{6}{|c|}{ Outcomes } \\
\hline Author & Population & Year & Type of study & $\begin{array}{l}\text { Follow- } \\
\text { up (mo) }\end{array}$ & Recurrence & OS & RFS & Metastases & $\begin{array}{c}\text { Progress to } \\
\text { treatment }\end{array}$ & $\begin{array}{c}\text { Decrease in } \\
\text { renal } \\
\text { function }\end{array}$ \\
\hline $\mathrm{Ma}^{1}$ & $\begin{array}{l}\text { T1a; RFA; } \\
\text { n=52 }\end{array}$ & 2014 & $\begin{array}{l}\text { Retrospective } \\
\text { review }\end{array}$ & 60 & $5.1 \%$ & $\begin{array}{l}\text { RFA: } \\
95.7 \% \\
(5-y r)\end{array}$ & $94.2 \%$ & $0 \%$ & $5.8 \%$ & \\
\hline Katsanos $^{2}$ & $\begin{array}{l}\text { T1a; RFA vs. } \\
\text { RN; n=587 }\end{array}$ & 2014 & Meta-analysis & 60 & $\begin{array}{c}3.6 \% \text { RFA } \\
3.6 \% \text { RN }\end{array}$ & - & $\begin{array}{c}\text { No } \\
\text { difference }\end{array}$ & - & $\begin{array}{c}7.2 \% \\
\text { retreatment } \\
\text { for RFA }\end{array}$ & $\begin{array}{c}\text {-14.6 MD of } \\
\text { eGFR decline } \\
\text { favouring } \\
\text { RFA }\end{array}$ \\
\hline Bahouth $^{3}$ & $\begin{array}{c}\text { T1a; AS; } \\
\text { n=70 }\end{array}$ & 2015 & $\begin{array}{c}\text { Retrospective } \\
\text { review }\end{array}$ & 34 & & $100 \%$ & - & $0 \%$ & $10 \%$ & - \\
\hline Olweny $^{4}$ & $\begin{array}{c}\text { T1a; } n=74 \\
\text { RFA vs. PN }\end{array}$ & $\begin{array}{l}1998- \\
2005\end{array}$ & $\begin{array}{l}\text { Retrospective } \\
\text { review }\end{array}$ & 72 & $\begin{array}{c}\text { PN: } 5 \% \\
\text { RFA: } 8 \%\end{array}$ & $\begin{array}{c}\text { PN: } 100 \% \\
\text { RFA: } \\
97 \%\end{array}$ & $\begin{array}{c}\text { CSS: } \\
\text { PN: } 100 \% \\
\text { RFA: } 97 \%\end{array}$ & $\begin{array}{c}\text { PN: } 8 \% \\
\text { RFA: } 3 \%\end{array}$ & PN: $3 \%$ & - \\
\hline Chang $^{5}$ & $\begin{array}{c}\text { T1a; } n=90 \\
\text { RFA vs. PN }\end{array}$ & 2015 & $\begin{array}{c}\text { Retrospective } \\
\text { review }\end{array}$ & 60 & $\begin{array}{l}\text { PN: } 4 \% \\
\text { RFA:5\% }\end{array}$ & $\begin{array}{c}\text { PN: 93\% } \\
\text { RFA: } \\
90 \%\end{array}$ & $\begin{array}{c}\text { Recurrence- } \\
\text { free } \\
\text { survival: } \\
\text { PN: } 98 \% \\
\text { RFA: } 95 \% \\
\text { Cancer- } \\
\text { specific } \\
\text { survival: } \\
\text { PN: } 98 \% \\
\text { RFA: } 96 \%\end{array}$ & $\begin{array}{c}\text { PN: } 4 \% \\
\text { RFA: } 4 \%\end{array}$ & - & $\begin{array}{c}\text { RFA: }-12 \% \\
\text { eGFR } \\
\text { PN: }-27 \% \\
\text { eGFR } \\
\text { No HD }\end{array}$ \\
\hline Park $^{6}$ & $\begin{array}{c}\text { T1a; } n=126 \\
\text { RFA vs. } \\
\text { RPN }\end{array}$ & 2018 & $\begin{array}{l}\text { Retrospective } \\
\text { review }\end{array}$ & 24 & $\begin{array}{l}\text { RPN: } 0 \% \\
\text { RFA: } 5 \%\end{array}$ & - & $\begin{array}{l}\text { RPN: } 100 \% \\
\text { RFA: } 95 \%\end{array}$ & $\begin{array}{l}\text { RPN: } 0 \% \\
\text { RFA: } 2 \%\end{array}$ & - & $\begin{array}{l}\text { RFA: }-13 \% \\
\text { eGFR } \\
\text { RPN: }-8 \% \\
\text { eGFR }\end{array}$ \\
\hline
\end{tabular}


Shared decision-making in the management of small renal masses

\begin{tabular}{|c|c|c|c|c|c|c|c|c|c|c|}
\hline & & & & & & & & & & $\begin{array}{c}\text { CKD III-IV: } \\
\text { RFA: } 13 \% \\
\text { RPN: } 10 \%\end{array}$ \\
\hline Pierorazio $^{7}$ & $\begin{array}{c}\text { T1a;n= } 497 \\
\text { AS vs. PI }\end{array}$ & 2015 & $\begin{array}{l}\text { Prospective } \\
\text { cohort }\end{array}$ & 25 & $\begin{array}{l}\text { Intervention: } \\
4 \%\end{array}$ & $\begin{array}{c}\text { PI: } 92 \% \\
\text { AS: } 75 \% \\
(5 \text { yrs })\end{array}$ & $\begin{array}{c}\text { CSS: } \\
\text { PI: } 99 \% \\
\text { AS: } 100 \%\end{array}$ & $\begin{array}{c}\text { Interventio } \\
\text { n: } 0.5 \% \\
\text { AS: } 0 \%\end{array}$ & $\begin{array}{l}\quad 9 \% \text { AS } \\
\text { crossover to } \\
\text { intervention }\end{array}$ & \\
\hline Jewett $^{8}$ & $\begin{array}{l}\text { T1a; AS; } \\
\text { n=178 }\end{array}$ & 2011 & $\begin{array}{c}\text { Prospective } \\
\text { cohort }\end{array}$ & 28 & & $94 \%$ & 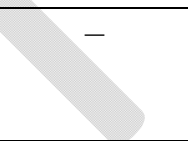 & $1 \%$ & $\begin{array}{c}12 \% \\
\text { progressed } \\
5 \% \text { treated }\end{array}$ & - \\
\hline Klatte $^{9}$ & $\begin{array}{c}\text { T1a; } \mathrm{n}=1191 \\
\text { PN vs CA }\end{array}$ & 2014 & Meta-analysis & 26 & $\begin{array}{l}\text { PN: } 0.4 \% \\
\text { CA: } 9.4 \%\end{array}$ & - & - & $\begin{array}{l}\text { PN: } 0.4 \% \\
\text { CA: } 4.4 \%\end{array}$ & - & - \\
\hline Gervais $^{10}$ & $\begin{array}{c}\text { T1a-T2; } \\
\mathrm{n}=85 ; \text { RFA }\end{array}$ & 2005 & $\begin{array}{c}\text { Retrospective } \\
\text { review }\end{array}$ & 27 & & $\begin{array}{l}\text { RFA: } \\
93 \%\end{array}$ & - & RFA: $0 \%$ & - & - \\
\hline Whitson $^{11}$ & $\begin{array}{c}\text { T1a; } \mathrm{n}=8818 \\
\text { RFA or CA } \\
\text { vs. PN }\end{array}$ & 2012 & $\begin{array}{l}\text { Retrospective } \\
\text { review }\end{array}$ & 34 & & $\begin{array}{c}\text { PN: } \\
98.3 \% \\
\text { RFA/CA: } \\
96.6 \% \\
\end{array}$ & $\begin{array}{c}\text { PN: } 98.2 \% \\
\text { RFA/CA: } \\
94.4 \% \\
(5 y r s)\end{array}$ & - & - & - \\
\hline Thompson $^{13}$ & $\begin{array}{c}\text { cT1; n=1424; } \\
\text { CA vs. RFA } \\
\text { vs. PN }\end{array}$ & 2015 & $\begin{array}{c}\text { Retrospective } \\
\text { review }\end{array}$ & 35 & $\begin{array}{c}\text { RFA: } 3 \% \\
\text { CA: } 2 \% \\
\text { PN: } 3 \%\end{array}$ & $\begin{array}{c}\text { PN: } 95 \% \\
\text { CA: } 88 \% \\
\text { RFA: } \\
82 \%\end{array}$ & $\begin{array}{c}\text { RFA: } 98 \% \\
\text { CA: } 98 \% \\
\text { PN: } 98 \%\end{array}$ & $\begin{array}{c}\text { PN: } 1.6 \% \\
\text { CA: } 0 \% \\
\text { RFA: } 2 \%\end{array}$ & - & - \\
\hline Maurice $^{14}$ & $\begin{array}{c}\text { T1; } \mathrm{n}=411 \\
\text { OPN vs. } \\
\text { RAPN }\end{array}$ & 2017 & $\begin{array}{c}\text { Retrospective } \\
\text { review }\end{array}$ & 6 & - & - & - & - & - & $\begin{array}{c}\text { eGFR } \\
\text { preservation: } \\
\text { OPN: } 90 \% \\
\text { RAPN: } 89 \%\end{array}$ \\
\hline
\end{tabular}


Shared decision-making in the management of small renal masses

\begin{tabular}{|c|c|c|c|c|c|c|c|c|c|c|}
\hline Pierorazio $^{15}$ & $\begin{array}{c}\text { T1-2; RFA } \\
\text { or CA vs. PN } \\
\text { vs. RN vs. } \\
\text { AS }\end{array}$ & 2016 & $\begin{array}{c}\text { Comparative } \\
\text { effectiveness } \\
\text { review }\end{array}$ & - & $\begin{array}{c}\text { PN: } 1-5 \% \\
\text { RFA: } 7-9 \%\end{array}$ & $\begin{array}{c}3 \text { yr: } \\
\text { RFA:84- } \\
94 \% \\
5 y r: \\
\text { PN: } 93 \% \\
\text { RN: } 86 \% \\
10 y r: \\
\text { PN: } 74 \% \\
\text { RN: } 71 \%\end{array}$ & $\begin{array}{c}\text { CSS: } \\
\text { RN: } 97 \% \\
\text { (T1a) } \\
\text { PN: } 99 \% \\
\text { (T1a) } \\
\text { RFA: 94\% } \\
\text { (5yr) }\end{array}$ & $\begin{array}{l}\text { PN: } 2-4 \% \\
\text { RN: } 4-6 \%\end{array}$ & - & $\begin{array}{c}\text { Change in } \\
\text { eGFR: } \\
\text { RN: }-39 \text { to - } \\
0.1 \\
\text { PN: }-18 \text { to }+4 \\
\text { RFA: }-8 \text { to }-2 \\
\text { AS: }-1 \text { to }-2 \\
\text { CKD III-IV: } \\
\text { RN: } 32-70 \% \\
\text { PN: } 12-20 \% \\
\text { RFA: } 13-28 \% \\
\text { AS: } 3 \% \\
\text { ESRD: } \\
\text { RN: } 1-3 \% \\
\text { PN: } 0.5-1 \% \\
\text { RFA: } 1-2 \%\end{array}$ \\
\hline Young $^{16}$ & $\begin{array}{l}\text { T1; RFA; } \\
\text { n=298 }\end{array}$ & 2012 & $\begin{array}{c}\text { Retrospective } \\
\text { review }\end{array}$ & 20 & RFA: $4 \%$ & - & RFA: $92 \%$ & RFA: $0.2 \%$ & - & - \\
\hline Patel $^{18}$ & $\begin{array}{l}\text { T1-2; RN vs. } \\
\text { PN vs. RFA } \\
\text { vs. AS }\end{array}$ & 2017 & Meta-analysis & - & & - & - & - & - & $\begin{array}{c}\text { Change in } \\
\text { eGFR: } \\
\text { RN: }-22 \\
\text { PN: }-7 \\
\text { RFA: }-6 \\
\text { AS: }-3\end{array}$ \\
\hline $\begin{array}{l}\text { Van } \\
\text { Poppel }^{19-21}\end{array}$ & $\begin{array}{c}\text { T1-T2; } \\
\mathrm{n}=541 ; \mathrm{RN} \\
\text { vs. PN }\end{array}$ & $\begin{array}{l}2007 \\
2011\end{array}$ & $\mathrm{RCT}$ & 112 & $\begin{array}{c}\text { PN: } 2 \% \\
\text { RN: } 0.4 \%\end{array}$ & $\begin{array}{c}\text { PN:76\% } \\
\text { RN:81\% } \\
(10 y r)\end{array}$ & - & $\begin{array}{l}\text { PN: } 3 \% \\
\text { RN: } 4 \%\end{array}$ & $\begin{array}{l}\text { PN: } 4 \% \\
\text { RN: } 3 \%\end{array}$ & $\begin{array}{c}\text { CKD III-IV: } \\
\text { PN: } 6.3 \% \\
\text { RN: } 10 \% \\
\text { ESRD: } \\
\text { PN: } 1.6 \% \\
\text { RN: } 1.5 \%\end{array}$ \\
\hline
\end{tabular}


AUA: American Urology Association; CA: cryoablation; CKD: chronic kidney disease; ESRD: end-stage renal disease; mo: months; OS: overall survival; ; PN: partial nephrectomy; RCT: randomized controlled trial; RFA: radiofrequency ablation; RFS: recurrence-free survival; RN: radical nephrectomy; -: do not report own data.

\begin{tabular}{|c|c|c|c|c|c|c|c|}
\hline \multicolumn{8}{|c|}{ 1C. Renal mass biopsy outcomes } \\
\hline & \multicolumn{2}{|c|}{ Study characteristics } & 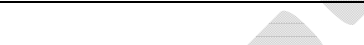 & \multicolumn{3}{|c|}{ Outcomes } & \\
\hline Author & Population & Year & Type of Study & Diagnostic & Bleeding & $\begin{array}{l}\text { Tumour } \\
\text { seeding }\end{array}$ & $\begin{array}{c}\text { Overall } \\
\text { complication rate }\end{array}$ \\
\hline Richard $^{23}$ & T1a; $n=373$ & 2017 & Retrospective review & $\begin{array}{c}87 \% \\
18 \% \text { benign }\end{array}$ & $0.6 \%$ & $0 \%$ & - \\
\hline Marconi $^{24}$ & $\mathrm{~T} 1 ; \mathrm{n}=5228$ & 2015 & Meta-analysis & $92 \%$ & $\begin{array}{c}4 \% \text { hematoma } \\
0.7 \% \text { transfusion } \\
3 \% \text { hematuria }\end{array}$ & $0.02 \%$ & $\begin{array}{c}8 \% \\
3 \% \text { lumbar pain }\end{array}$ \\
\hline Pierorazio $^{15}$ & $\mathrm{~T} 1-2 ; \mathrm{n}=2422$ & 2016 & $\begin{array}{c}\text { Comprehensive } \\
\text { effectiveness review }\end{array}$ & - & $\begin{array}{c}5 \% \text { hematoma } \\
0.4 \% \text { hemorrhage }\end{array}$ & $0 \%$ & $1.2 \%$ pain \\
\hline
\end{tabular}

\section{References}

1. Ma Y, Bedir S, Cadeddu JA, Gahan JC. Long-term outcomes in healthy adults after radiofrequency ablation of T1a renal tumours. BJU Int. 2014;113(1):51-55. doi:10.1111/bju.12366.

2. Katsanos K, Mailli L, Krokidis M, McGrath A, Sabharwal T, Adam A. Systematic review and meta-analysis of thermal ablation versus surgical nephrectomy for small renal tumours. Cardiovasc Intervent Radiol. 2014;37(2):427-437. doi:10.1007/s00270-0140846-9.

3. Bahouth Z, Halachmi S, Meyer G, Avitan O, Moskovitz B, Nativ O. The natural history and predictors for intervention in patients with small renal mass undergoing active surveillance. Adv Urol. 2015;2015. doi:10.1155/2015/692014.

4. Olweny EO, Park SK, Tan YK, Best SL, Trimmer C, Cadeddu JA. Radiofrequency ablation versus partial nephrectomy in patients with solitary clinical tla renal cell carcinoma: Comparable oncologic outcomes at a minimum of 5 years of follow-up. Eur Urol. 2012;61(6):1156-1161. doi:10.1016/j.eururo.2012.01.001.

5. Chang X, Liu T, Zhang F, et al. Radiofrequency ablation versus partial nephrectomy for clinical T1a renal-cell carcinoma: longterm clinical and oncologic outcomes based on a propensity score analysis. $J$ Endourol. 2015;29(5):518-525. doi:10.1089/end.2014.0864. 
6. Park BK, Gong IH, Kang MY, et al. RFA versus robotic partial nephrectomy for T1a renal cell carcinoma: a propensity scorematched comparison of mid-term outcome. European Radiology. 2018:1-7.

7. Pierorazio PM, Johnson MH, Ball MW, et al. Five-year Analysis of a Multi-institutional Prospective Clinical Trial of Delayed Intervention and Surveillance for Small Renal Masses: The DISSRM Registry. Eur Urol. 2015;68(3):408-415. doi:10.1016/j.eururo.2015.02.001.

8. Jewett MAS, Mattar K, Basiuk J, et al. Active surveillance of small renal masses: Progression patterns of early stage kidney cancer. Eur Urol. 2011;60(1):39-44. doi:10.1016/j.eururo.2011.03.030.

9. Klatte T, Shariat SF, Remzi M. Systematic Review and Meta-Analysis of Perioperative and Oncologic Outcomes of Laparoscopic Cryoablation Versus Laparoscopic Partial Nephrectomy for the Treatment of Small Renal Tumors. J Urol. 2014;191(5):1209-1217. doi:10.1016/j.juro.2013.11.006.

10. Gervais DA, McGovern FJ, Arellano RS, McDougal WS, Mueller PR. Radiofrequency Ablation of Renal Cell Carcinoma: Part 1, Indications, Results, and Role in Patient Management over a 6-Year Period and Ablation of 100 Tumors. Am J Roentgenol. 2005;185(1):64-71. doi:10.2214/ajr.185.1.01850064.

11. McKiernan JM, Whitson JM, Harris CR, Meng M V. Population-based comparative effectiveness of nephron-sparing surgery vs ablation for small renal masses. BJU Int. 2012:1-6. doi:10.1111/j.1464-410X.2012.11113.

12. Pavlovich CP, Walther MM, Choyke PL, et al. Percutaneous radio frequency ablation of small renal tumors: Initial results. 2014;167(1):10-15.

13. Thompson RH, Atwell T, Schmit G, et al. Comparison of partial nephrectomy and percutaneous ablation for cT1 renal masses. Eur Urol. 2015;67(2):252-259. doi:10.1016/j.eururo.2014.07.021.

14. Maurice MJ, Ramirez D, Kara Ö, et al. Optimum outcome achievement in partial nephrectomy for T1 renal masses: a contemporary analysis of open and robot-assisted cases. BJU Int. 2017;120(4):537-543. doi:10.1111/bju.13888.

15. Pierorazio M, Johnson, MH PH, Sozio S, et al. Management of Renal Masses and Localized Renal Cancer. Comp Eff Rev. 2016; Review No.

16. Young EE, Castle SM, Gorbatiy V, Leveillee RJ. Comparison of safety, renal function outcomes and efficacy of laparoscopic and percutaneous radio frequency ablation of renal masses. J Urol. 2012;187(4):1177-1182. doi:10.1016/j.juro.2011.11.099.

17. Tsai S-H, Tseng P-T, Sherer BA, et al. Open versus robotic partial nephrectomy: Systematic review and meta-analysis of contemporary studies. Int J Med Robot Comput Assist Surg. 2018;(January):e1963. doi:10.1002/rcs.1963.

18. Patel HD, Pierorazio PM, Johnson MH, et al. Renal functional outcomes after surgery, ablation, and active surveillance of localized renal tumors: A systematic review and meta-analysis. Clin J Am Soc Nephrol. 2017;12(7):1057-1069. doi:10.2215/CJN.11941116.

19. Van Poppel H, Da L, Albrecht W, et al. A Prospective, Randomised EORTC Intergroup Phase 3 Study Comparing the Oncologic Outcome of Elective Nephron-Sparing Surgery and Radical Nephrectomy for Low-Stage Renal Cell Carcinoma. Eur Urol. 
2011;59(4):543-552. doi:10.1016/j.eururo.2010.12.013.

20. Van Poppel H, Da Pozzo L, Albrecht W, et al. A Prospective Randomized EORTC Intergroup Phase 3 Study Comparing the Complications of Elective Nephron-Sparing Surgery and Radical Nephrectomy for Low-Stage Renal Cell Carcinoma \{A figure is presented\}. Eur Urol. 2007;51(6):1606-1615. doi:10.1016/j.eururo.2006.11.013.

21. Scosyrev E, Messing EM, Sylvester R, Campbell S, Poppel H Van. Renal Function After Nephron-sparing Surgery Versus Radical Nephrectomy : Results from EORTC Randomized Trial 30904. Eur Urol. 2014;65(2):372-377. doi:10.1016/j.eururo.2013.06.044.

22. Potretzke AM, Knight BA, Zargar H, et al. Urinary fistula after robot-assisted partial nephrectomy: A multicentre analysis of 1791 patients. BJU Int. 2016;117(1):131-137. doi:10.1111/bju.13249.

23. Richard PO, Jewett MAS, Tanguay S, et al. Safety, reliability and accuracy of small renal tumour biopsies: results from a multiinstitution registry. BJU Int. 2017;119(4):543-549. doi:10.1111/bju.13630.

24. Marconi L, Dabestani S, Lam TB, et al. Systematic review and meta-analysis of diagnostic accuracy of percutaneous renal tumour biopsy. Eur Urol. 2016;69(4):660-673. doi:10.1016/j.eururo.2015.07.072. 